Kong. Res. J. 2(1) : 56-62, 2015

ISSN 2349-2694

Kongunadu Arts and Science College, Coimbatore.

\title{
PHYTOSOCIOLOGICAL ANALYSIS OF THE MEDICINAL PLANT SPECIES, THALICTRUM JAVANICUM BLUME IN THOTTABETTA, NILGIRIS, THE WESTERN GHATS.
}

\author{
Abinaya .G. and S. Paulsamy* \\ Department of Botany, Kongunadu Arts and Science College, Coimbatore-641 029, Tamil Nadu, India. \\ *E-mail: paulsami@yahoo.com
}

\section{ABSTRACT}

Phytosociological study is the most essential in any community to know its structure and organization. The various qualitative characters obtained are used to determine the level of distribution, numerical strength and degree of dominance exhibited by the constituent species in the community. Thalictrum javanicum belongs to the family Ranunculaceae family, it is medium sized erect herb, found in the temperate Himalayas from Kasmir to Sikkim in Khasi hills, and Kodaikanal and Nilgiri hills of Western Ghats in Tamil Nadu, India. At global level, it is generally distributed in the hilly tracts of India, Srilanka, China and Java at the altitude of around $2400 \mathrm{~m}$ above msl. The present study was undertaken in Thottabetta, the Nilgiris by sampling using belt transects of $10 \times 1000 \mathrm{~m}$ size which further divided into 100 segments each which $10 \times 10 \mathrm{~m}$ size. The total number of species encountered in the study area is 45 which includes 5 grasses and 40 forbs. The quantitative ecological characters of the study species, T. javanicum is a detailed below: frequency $11 \%$, abundance 3.82 individuals $/ \mathrm{m}^{2}$, density 0.42 individuals $/ \mathrm{m}^{2}$, basal cover $172.20 / \mathrm{mm}^{2} / \mathrm{m}^{2}$, relative frequency $0.55 \%$ and relative density $0.08 \%$, relative dominance $0.16 \%$. Based on the ecological attributes it is determined that the species, T. javanicum is less perpetuated in the community studied. Hence, further studies on the determination of propagation strategies for population enhancement and conservation of wilds are suggested.

Keywords: Phytosociological study, qualitative characters and quantitative ecological characters.

\section{INTRODUCTION}

Phytosociology is the study of the characteristics, classification, relationships and distribution of plant communities. These studies are most essential to understand the species diversity, community organization and to select out useful plant species from natural communities (Daubenmire, 1970), and to know the ecological status of the constituent species in the communities (Katsuno, 1977). Ecological status of species in a habitat is determined by assessing the biodiversity of a region, the environmental conditions prevailing there and their interactions. Ecological assessment is done by evaluation of the components along with its functional abilities of an ecosystem. This includes the assessment of species diversity, frequency and their importance value index and threat to their habitat by anthropogenic activities which may alter the physical, chemical and biological integrity of the system (Manoj et al., 2012). In light of this fact, certain ecological tools were employed to determine quantitative ecological characters such as frequency, abundance, density, basal cover and their importance value index for all the constituent species along with the study species, Thalictrum javanicum to know the current ecological position of
T. javanicum in its major area of occurrence, Thottabetta, Nilgiris, the Western Ghats.

\section{MATERIALS AND METHODS}

\subsection{Study area}

The study was carried out in Thottabetta, Nilgiris, the Western Ghats, Tamil Nadu, India situated at $11^{\circ} 24^{\prime} 08.7^{\prime \prime} \mathrm{N}$ and $76^{\circ} 44^{\prime} 12.2^{\prime \prime} \mathrm{E}$. The Nilgiri plateau covers an area of ca. 2,000 $\mathrm{Km}^{2}$. The climate is of the tropical montane type (MeherHomji, 1967). The mean monthly temperature varies between $5^{\circ} \mathrm{C}$ (January) and $24^{\circ} \mathrm{C}$ (April) (Von Lengerke, 1977). The data on climatic factors of the study area was given in Table 1 . During the study period, the lowest and highest minimum temperatures have varied between 9.1 (December, 2012) and $15.8^{\circ} \mathrm{C}$ (May, 2013). On the other hand, the lowest and highest maximum temperatures have recorded as 11.5 (January, 2013) and $26.3^{\circ} \mathrm{C}$ (May, 2013) respectively. The dry season lasts from January to April and less rainfall occurred during November to June. The mean annual rainfall recorded at Thottabetta between June, 2012 and May, 2013 was $1688.2 \mathrm{~mm}$. The area is exposed to southwest monsoon during June-September and to the northeast monsoon during October-November. 
The altitude of the study area is $2400 \mathrm{~m}$ above msl. The relative humidity was ranging from $73 \%$ (April, 2013) to 93\% (October, 2012).

The vegetation is mainly sholas with grasslands and extensive private tea plantations and exotic tree plantations (Acacia mearnsii, A. dealbata, Eucalyptus globulus, Pinus longifolia, etc.) managed by the Forest Department. The largest resident mammalian herbivore is the Sambar (Cervus unicolor). Elephants (Elephas maximus) visit the area particularly in January-March, during the dry season. Large predators include tiger (Panthera tigris) and leopard (Panthera pardus) are also sighted.

\subsection{Methods}

In order to study the phytosociological characters of the traditional medicinal herb, Thalictrum javanicum, Thottabetta of the Nilgiri District was selected as it is inhabiting better than the other areas of Nilgiris. For this, a one hectare rectangular plot (10X1000m) was established during Febraury, 2012. Each plot was subdivided into 100 subplots of $10 \times 10 \mathrm{~m}$ size. The occurrence with the individuals of $T$. javanicum, was recorded in each subplot to determine its frequency, density and abundance in the communities (Cottom and Curtis, 1956). Importance value index (IVI) was computed by summing up relative frequency, relative density and relative basal area. Distribution levels were also noted for other associated species available in the study area.

Frequency, density and abundance were calculated using the following formulae:

$$
\begin{gathered}
\text { Frequency }(\%)=\frac{\text { Number of quadrats in which the species present }}{\text { Total number of quadrats studied }} \times 100 \\
\text { Density }=\frac{\text { Total number of individuals of the species in all quadrats }}{\text { Total number of quadrats studied }} \\
\text { Abundance }=\frac{\text { Total number of individuals of the species in all quadrats }}{\text { Number of quadrats of occurrence of the species }}
\end{gathered}
$$

To calculate average basal area of individuals, the stem circumference at $30 \mathrm{~cm}$ high from soil for each species was measured. Then the formula, $\pi r^{2}$ was used to derive the average basal area. The average basal area was multiplied with the density to obtain the basal cover.

Relative frequency, relative density and relative dominance were calculated from the following formulae

$$
\begin{aligned}
& \text { Relative frequency }(\%)=\frac{\text { Number of occurence of the species }}{\text { Number of occurence of all specie }} \times 100 \\
& \text { Relative density }(\%)=\frac{\text { Number of individuals of the species }}{\text { Number of individuals of all species }} \times 100 \\
& \text { Relative dominance }(\%)=\frac{\text { Total basal area of the species }}{\text { Total basal area of all species }} \times 100
\end{aligned}
$$

The importance value index (IVI) and the relative value of importance (RVI) were calculated as per the method of Curtis and Mc Intosh, (1950).

Importance value index (IVI) is the sum of quantities of relative frequency, relative density and relative dominance expressed per 300 .

Relative value of importance (RVI) was calculated by using the formula: $\mathrm{RVI}=\frac{\mathrm{IVI}}{3}$

\section{RESULTS AND DISCUSSION}

\subsection{Climatic data of the studyarea}

The climatic data of the study area is presented in Table 1 . The range of temperature over the study period was existing between 9.1 (December, 2012) and $26.3^{\circ} \mathrm{C}$ (May, 2013). The annual rainfall during the study period of June, 2012 - May, 2013 was $1688.2 \mathrm{~mm}$. Rainfall was mostly through south-west and north-east monsoons (June - November) and the remaining months in the year were generally dry. The relative humidity ranged from 73\% (April, 2013) to $93 \%$ (October, 2012). The climatic data particularly the temperature (maximum of $26.3^{\circ} \mathrm{C}$ ) showed that the study area is experiencing temperate climate. The rainfall and humidity data exhibited that the study area is also having favorable environmental factors for plant growth.

\subsection{Floristic analysis}

A total number of 45 plant species was enlisted in the study area which includes 5 grasses (11.11\%) and 40 forbs (88.89\%) (Table 2).

\subsection{Family-wise composition}

A total number of 24 plant families was recorded (Table 2). Overall, the family, Poaceae has the highest number of individuals 43,851/ha (Agrostis peninsularis -11628 individuals/ha, Cynodon dactylon - 9855 individuals/ha, C. barberi9688 individuals/ha, Brachiaria semiverticillatta8365 individuals/ha and Digitara ternata - 4315 individuals/ha). On the other hand, the families Geraniaceae (Impatiens leschenaultii- 13 individuals/ha and I. modesta - 9 individuals/ha), Boraginaceae (Cynoglossum zeylanicum - 11 individuals), Acanthaceae (Strobilanthes kunthiana- 
13 individuals/ha) and Ranunculaceae (Thalictrum javanicum - 42 individuals/ha) have least number of individuals. In the present study a total number of 45 plant species which includes 5 grasses and 40 forbs. The Poaceae was predominant plant family in the present study site, while Geraniaceae, Boraginaceae, Acanthaceae and Ranunculaceae constituted only least number of individuals. Michael and Boodram, (2006) found the similar trend of dominance of Poaceae members in the similar climatic dry forest vegetation communities of little Tobago Island, West Indies.

\subsection{Frequency}

Frequency is usually expressed in terms of percentage occurrence of individual species in an area. The highest frequency of $100 \%$ in the studied community was registered by the grass species viz; Agrostis peninsularis, Brachiaria semiverticillatta, Cynodon barberi, C. dactylon, and Digitara ternata and the forbs, Erigeron karvinskianus has highest frequency (93\%). It indicates that these six species have fitted well with the environment of Thottabetta region. The higher seed output and greater reproductive potential exist in these species may be the possible reasons for this fact (Khoshoo and Mahal, 1967; Manorama, 1996). The species such as Cynoglossum zeylanicum, Hypochaeris radicata, Impatiens leschenaultii, I. modesta, Strobilanthes kunthiana and Thalictrum javanicum were present with lower frequencies of $6,8,6,5,8$ and $11 \%$ respectively (Table 3 ). It may be attributed to its microclimatic preference for the appearance of these species only in the margins of the forests and not the entire stretch of the forests.

\subsection{Abundance}

Abundance refers to the number of individuals per unit area on basis of the number of quadrats of occurrence and it is not like the density where the number of all quadrats studied in the community is taken into account. Among the different species analyzed the highest abundance value was obtained by the species, Agrostis peninsularis $\left(116.28 / \mathrm{m}^{2}\right)$ followed by Cynodon dactylon $\left(98.55 / \mathrm{m}^{2}\right)$, C. barberi $\left(96.88 / \mathrm{m}^{2}\right)$ and Brachiaria semiverticillatta $\left(83.65 / \mathrm{m}^{2}\right)$, and the lowest abundance was obtained by the species Pteris cretica $\left(1.05 / \mathrm{m}^{2}\right)$, Psoralea pinnata $\left(1.07 / \mathrm{m}^{2}\right)$, Pteris quadriauriata $\left(1.09 / \mathrm{m}^{2}\right)$, Anaphalis elliptica $\left(1.10 / \mathrm{m}^{2}\right)$ and Thalictrum javanicum $\left(3.82 / \mathrm{m}^{2}\right)$ (Table 3$)$. This indicates the higher concentration of these species in limited area which in tern may be influenced by dispersal mechanism of the respective species. However, the study species, Thalictrum javanicum obtained the less abundance of $3.82 / \mathrm{m}^{2}$ which indicates slightly wider distribution with lower numerical strength. Therefore, despite the existence of good dispersal mechanism, the fitness to the habitat in terms of population size is not appreciable in comparison to that of other species.

\subsection{Density}

The density is the most important quantitative character of any species in a community to know its structural and functional contribution to the ecosystem. In addition, determination of density for a species is more useful to know its distribution and microclimatic preferences in a common macroclimatic condition. The density of studied community showed that the species, Agrostis peninsularis has recorded higher density of $116.28 / \mathrm{m}^{2}$. However, the study species, Thalictrum javanicum has present with very lower value of density $\left(0.42 / \mathrm{m}^{2}\right)$ in the community studied (Table 3 ) and it is not comparable to that of the other species. The poor reproductive potential with less seed output and weaker competitive ability may lead the species with low density in the communities (Chandrasekaran and Swamy, 1995). Further, it is known that because of the medicinal properties, the species, T. javanicum is being exploited by the local people severely (Paulsamy, 2007), though the sholas are being given intensive protection by in situ conservation of the valuable species present in the study area. This fact may also be a reason for the lower density of $T$. javanicum in the study area.

\subsection{Basal cover}

On the basis of increasing or decreasing values of basal cover and importance value index, species have been classified as 'increasers' and 'decreasers' (Daubenmire, 1940; Weaver and Hansen, 1941; Dyksterhuis, 1949; Weaver and Albertson, 1956). The basal cover of the constituent species in the studied community was varied widely (Table 3 ). It was determined to be higher for the forbs, Cyperus digitatus $\left(2873.90 / \mathrm{mm}^{2} / \mathrm{ha}\right)$ and $C$. esculentus $\left(2343.60 / \mathrm{mm}^{2} / \mathrm{ha}\right)$. The basal cover occupied by the study species, Thalictrum javanicum $\left(172.20 / \mathrm{mm}^{2} / \mathrm{ha}\right)$ was not comparable to that of the forbs mentioned above (Table 3 ) which indicates its less role in community metabolism. It may be explained due to herbaceous nature of this species which naturally expected to have very small sized stem. This feature results in lesser basal area of individuals of the study species. Secondly, the less density value obtained by this species may also leads to the occupation of less basal cover, since this character is the manipulation of the attribute, density for the species of homogenous communities. In general, based on the basal cover, it is known that 
all the species were mere present in the forest margins of the study area and they have no major functional role in the community metabolism.

\subsection{Relative values of frequency, density and dominance}

The values of relative frequency, relative density and relative dominance are the magnification of the quantitative characters such as frequency, density and basal area respectively. Hence, the studied community exhibited the similar trend of values for these characters as exhibited by the characters, frequency, density and basal cover for all the species including Thalictrum javanicum (Table 3).

\subsection{Importance value index (IVI)}

In order to express the ecological success of any species with a single value, the concept of importance value index has been developed. The quantitative values of relative frequency, relative density and relative dominance are added to get the IVI. It gives the idea on ecological success of any species with a single value. The IVI of the constituent species in the studied community was ranging between 0.29 and 47.31. The Poaceae members viz; as Agrostis peninsularis, Cynodon dactylon, Brachiaria semiverticillatta and Cynodon barberi have scored

the highest IVI of 47.31, 42.65, 42.27 and 41.13 respectively. The presence of higher ecological

importance for these species in the study area showed that they are having well adaptive mechanism against the disturbance. The higher seed output with greater germination percentage and survivability rate may also assist these species for their stronger perpetuation (Paulsamy, 2005). On the other hand, the lowest IVI value was scored by the Geraniaceae member, Impatiens modesta (0.29). The study species, Thalictrum javanicum has also registered lower IVI value of 0.79 only. It showed that this species has less perpetuation in the community of Thottabetta than the other associated species (Table 3). The absence of adequate microsites for this species may also be pointed out as reason for the lower IVI of these species (Paulsamy, 2006). Further, it is known that the impact of environment on this species was also not noteworthy.

\subsection{Relative value of importance (RVI)}

RVI is an ecological character, which showed the importance of particular species in relation to other constituent species present in the community by considering the attributes, frequency, density and dominance. Since it is a manipulated character of IVI, it exhibited the values in the same trend as shown by the IVI. The RVI of the constituent species in the studied community was ranging between 0.10 and 15.77\%. The Poaceae members such as Agrostis peninsularis followed by Cynodon dactylon, Brachiaria semiverticillatta and C. barberi have scored the highest RVI of 15.77, 14.22, 14.09 and $13.71 \%$ respectively. On the other hand, the lowest RVI value was scored by the Geraniaceae member, Impatiens modesta $(0.10 \%)$ and the studied Ranunculaceae member, Thalictrum javanicum (0.26\%) (Table 3).

\section{CONCLUSION}

From the phytosociological studies it is concluded that the species, Thalictrum javanicum is considered to have very less ecological importance. Based on the quantitative ecological characters in terms of frequency, density and basal cover, it is investigated that this species is less perpetuated in the community. Further studies on autecological aspects will be carried out to diagnose factors responsible for its poor status and so to device new strategies of propagation to establish the species.

Table 1. Climatic data of the study area, Thottabetta, the Nilgiris, Western Ghats.

\begin{tabular}{|c|c|c|c|c|c|}
\hline \multirow{2}{*}{$\begin{array}{l}\text { Year and } \\
\text { Month }\end{array}$} & \multicolumn{2}{|c|}{$\begin{array}{c}\text { Temperature } \\
\left({ }^{\circ} \mathrm{C}\right)\end{array}$} & \multirow{2}{*}{$\begin{array}{c}\text { Rainfall } \\
\text { (mm) }\end{array}$} & \multirow{2}{*}{$\begin{array}{r}\text { Rainy } \\
\text { Days }\end{array}$} & \multirow{2}{*}{$\begin{array}{l}\text { Relative } \\
\text { humidity } \\
(\%)\end{array}$} \\
\hline & Max. & Min. & & & \\
\hline $\begin{array}{l}2012 \\
\text { Jun }\end{array}$ & 20.4 & 15.3 & 271.3 & 17 & 75 \\
\hline Jul & 18.4 & 14.0 & 290.2 & 21 & 85 \\
\hline Aug & 17.6 & 14.2 & 271.0 & 18 & 80 \\
\hline Sep & 18.2 & 15.0 & 190.2 & 14 & 92 \\
\hline Oct & 16.8 & 14.1 & 315.1 & 20 & 93 \\
\hline Nov & 14.5 & 9.3 & 230.5 & 15 & 90 \\
\hline Dec & 13.2 & 9.1 & 44.8 & 3 & 83 \\
\hline $\begin{array}{l}2013 \\
\text { Jan }\end{array}$ & 11.5 & 10.0 & 0.0 & 0 & 85 \\
\hline Feb & 13.2 & 10.4 & 7.8 & 1 & 85 \\
\hline Mar & 19.4 & 10.9 & 43.2 & 3 & 90 \\
\hline Apr & 22.0 & 15.2 & 12.8 & 2 & 73 \\
\hline May & 26.3 & 15.8 & 11.3 & 2 & 80 \\
\hline
\end{tabular}


Table 2. Species composition: species and their included family, number of individuals and number of quadrats of occurrence of constituent species in the studied community at Thottabetta, Nilgiris, the Western Ghats.

\begin{tabular}{|c|c|c|c|}
\hline Name of the species & Family & $\begin{array}{c}\text { Number } \\
\text { of } \\
\text { individuals /ha }\end{array}$ & $\begin{array}{c}\text { Number of quadrats of } \\
\text { occurrence }\end{array}$ \\
\hline $\begin{array}{l}\text { Grasses } \\
\text { Agrostis peninsularis H\&F. }\end{array}$ & Poaceae & 11628 & 100 \\
\hline Brachiaria semiverticillatta Alston. & Poaceae & 8365 & 100 \\
\hline Cynodon barberi Rang\& Tad. & Poaceae & 9688 & 100 \\
\hline C. dactylon Pers. & Poaceae & 9855 & 100 \\
\hline Digitara ternata Stapf. & Poaceae & 4315 & 100 \\
\hline $\begin{array}{l}\text { Forbs } \\
\text { Adiantum concinnum Wild. }\end{array}$ & Adiantaceae & 369 & 48 \\
\hline A. raddianum Presl. & Adiantaceae & 218 & 43 \\
\hline Anaphalis elliptica Dc. & Asteraceae & 65 & 59 \\
\hline A. subdecurrens, Gamb. & Asteraceae & 94 & 84 \\
\hline Anemone rivularis Ham. & Ranunculaceae & 84 & 59 \\
\hline Arisaema leschenaultti $\mathrm{Bl}$. & Araceae & 15 & 13 \\
\hline Cardamine africana $\mathrm{L}$. & Brassicaceae & 21 & 15 \\
\hline Crotalaria laevigata Lam. & Fabaceae & 19 & 15 \\
\hline Cynoglossum zeylanicum cl. & Boraginaceae & 11 & 6 \\
\hline Cyperus digitatus Roxb & Cyperaceae & 991 & 89 \\
\hline C. esculentus Linn. & Cyperaceae & 868 & 83 \\
\hline Eria sp. & Orchidaceae & 33 & 19 \\
\hline Erigeron alpinus L. & Asteraceae & 698 & 89 \\
\hline E. karvinskianus Dc. & Asteraceae & 715 & 93 \\
\hline Euphorbia rothiana Spr. & Euphorbiaceae & 49 & 35 \\
\hline Fragraia indica Andr. & Rosaceae & 36 & 30 \\
\hline Fimbristylis tetrogana $\mathrm{RBr}$. & Cyperaceae & 210 & 69 \\
\hline Hypochaeris radicata $\mathrm{L}$. & Asteraceae & 15 & 8 \\
\hline Impatiens leschenaultii Wall. & Geraniaceae & 13 & 6 \\
\hline I. modesta W. & Geraniaceae & 9 & 5 \\
\hline Microlepia manjuscula (Lowe) Moore Ind. Fill. & Dennstaedtiaceae & 26 & 18 \\
\hline Myriactis wightii Dc. & Asteraceae & 46 & 21 \\
\hline Odontosoria chinensis (L). & Lindsaeaceae & 35 & 19 \\
\hline Oxalis corniculata $\mathrm{L}$. & Oxalidaceae & 319 & 63 \\
\hline O. pubescens L. & Oxalidaceae & 405 & 71 \\
\hline Pilea trinervia $\mathrm{W}$. & Utricaceae & 30 & 21 \\
\hline P. wightii Wedd. & Utricaceae & 41 & 23 \\
\hline Pogostemon travancoricus Bedd. & Lamiaceae & 65 & 36 \\
\hline Polygonum chinense Linn. & Polygonaceae & 28 & 23 \\
\hline Psoralea pinnata $\mathrm{L}$. & Fabaceae & 45 & 42 \\
\hline Pteris cretica L.Mant & Pteridaceae & 63 & 60 \\
\hline P. quadriauriata .Retz & Pteridaceae & 93 & 85 \\
\hline Rubus racemosus Roxb. & Rosaceae & 41 & 30 \\
\hline R. ellipticus Sm. & Rosaceae & 53 & 41 \\
\hline Solanum nigrum $\mathrm{L}$. & Solanaceae & 31 & 19 \\
\hline Strobilanthes kunthiana T. And. & Acanthaceae & 13 & 8 \\
\hline Thalictrum javanicum Blume. & Ranunculaceae & 42 & 11 \\
\hline Ulex europaeus $\mathrm{L}$. & Fabaceae & 38 & 16 \\
\hline Viola serpens Wall. & Violaceae & 46 & 31 \\
\hline V. patrini Dc. & Violaceae & 55 & 35 \\
\hline
\end{tabular}

Table 3. Frequency, abundance, density and basal cover with their relative values, importance value index (IVI) and relative value of importance (RVI) of constituent species in the community at Thottabetta, Nilgiris, the Western Ghats.

\begin{tabular}{|c|c|c|c|c|c|c|c|c|c|c|}
\hline S.No & Name of the species & $\begin{array}{c}F \\
(\%)\end{array}$ & $\begin{array}{c}\mathrm{A} \\
\begin{array}{c}\text { (individuals } \\
/ \mathbf{m}^{2} \text { ) }\end{array} \\
\end{array}$ & $\begin{array}{c}\mathrm{D} \\
\text { (individuals } \\
/ \mathrm{m}^{2} \text { ) }\end{array}$ & $\begin{array}{c}\text { BC } \\
\left(\mathrm{mm}^{2} / \mathrm{ha}\right)\end{array}$ & $\begin{array}{l}\text { R.F } \\
\text { (\%) }\end{array}$ & $\begin{array}{l}\text { R.De } \\
\text { (\%) }\end{array}$ & $\begin{array}{l}\text { R.Do } \\
\text { (\%) }\end{array}$ & IVI & $\begin{array}{l}\text { RVI } \\
\text { (\%) }\end{array}$ \\
\hline 1. & $\begin{array}{l}\text { Grasses } \\
\text { Agrostis peninsularis }\end{array}$ & 100 & 116.28 & 116.28 & 20930.40 & 4.97 & 23.30 & 19.04 & 47.31 & 15.77 \\
\hline 2. & $\begin{array}{l}\text { Brachiaria } \\
\text { semiverticillatta }\end{array}$ & 100 & 83.65 & 83.65 & 22585.50 & 4.97 & 16.76 & 20.54 & 42.27 & 14.09 \\
\hline 3. & Cynodon barberi & 100 & 96.88 & 96.88 & 18407.20 & 4.97 & 19.42 & 16.74 & 41.13 & 13.71 \\
\hline 4. & C. dactylon & 100 & 98.55 & 98.55 & 19710.00 & 4.97 & 19.75 & 17.93 & 42.65 & 14.22 \\
\hline 5. & Digitara ternata & 100 & 43.15 & 43.15 & 10787.50 & 4.97 & 8.65 & 9.81 & 23.43 & 7.81 \\
\hline
\end{tabular}




\begin{tabular}{|c|c|c|c|c|c|c|c|c|c|c|}
\hline & Forbs & & & & & & & & & \\
\hline 6. & Adiantum concinnum & 48 & 7.69 & 3.69 & 1033.20 & 2.38 & 0.74 & 0.94 & 4.06 & 1.35 \\
\hline 7. & A. raddianum & 43 & 5.07 & 2.18 & 654.00 & 2.14 & 0.44 & 0.59 & 3.17 & 1.06 \\
\hline 8. & Anaphalis elliptica & 59 & 1.10 & 0.65 & 201.50 & 2.93 & 0.13 & 0.18 & 3.24 & 1.08 \\
\hline 9. & A. subdecurrens & 84 & 1.12 & 0.94 & 291.40 & 4.17 & 0.19 & 0.27 & 4.63 & 1.54 \\
\hline 10. & Anemone rivularis & 59 & 1.42 & 0.84 & 277.20 & 2.93 & 0.17 & 0.25 & 3.35 & 1.12 \\
\hline 11. & Arisaema leschenaultti & 13 & 1.15 & 0.15 & 57.00 & 0.65 & 0.03 & 0.05 & 0.73 & 0.24 \\
\hline 12. & Cardamine Africana & 15 & 1.40 & 0.21 & 58.80 & 0.74 & 0.04 & 0.05 & 0.83 & 0.28 \\
\hline 13. & Crotalaria laevigata & 15 & 1.27 & 0.19 & 55.10 & 0.74 & 0.04 & 0.05 & 0.83 & 0.28 \\
\hline 14. & $\begin{array}{l}\text { Cynoglossum } \\
\text { zeylanicum }\end{array}$ & 6 & 1.83 & 0.11 & 22.00 & 0.30 & 0.02 & 0.02 & 0.34 & 0.11 \\
\hline 15. & Cyperus digitatus & 89 & 11.13 & 9.91 & 2873.90 & 4.42 & 1.99 & 2.61 & 9.02 & 3.01 \\
\hline 16. & C. esculentus & 83 & 10.46 & 8.68 & 2343.60 & 4.12 & 1.74 & 2.13 & 7.99 & 2.66 \\
\hline 17. & Eria sp. & 19 & 1.74 & 0.33 & 99.00 & 0.94 & 0.07 & 0.09 & 1.10 & 0.37 \\
\hline 18. & Erigeron alpinus & 89 & 7.84 & 6.98 & 1884.60 & 4.42 & 1.40 & 1.71 & 7.53 & 2.51 \\
\hline 19. & E. karvinskianus & 93 & 7.69 & 7.15 & 2073.50 & 4.62 & 1.43 & 1.89 & 7.94 & 2.65 \\
\hline 20. & Euphorbia rothiana & 35 & 1.40 & 0.49 & 98.00 & 1.74 & 0.10 & 0.09 & 1.93 & 0.64 \\
\hline 21. & Fragraia indica & 30 & 1.20 & 0.36 & 93.60 & 1.49 & 0.07 & 0.09 & 1.65 & 0.55 \\
\hline 22. & Fimbristylis tetrogana & 69 & 3.04 & 2.1 & 651.00 & 3.43 & 0.42 & 0.59 & 4.44 & 1.48 \\
\hline 23. & Hypochaeris radicata & 8 & 1.88 & 0.15 & 30.00 & 0.40 & 0.03 & 0.03 & 0.46 & 0.15 \\
\hline 24. & Impatiens leschenaultii & 6 & 2.17 & 0.13 & 32.50 & 0.30 & 0.03 & 0.03 & 0.36 & 0.12 \\
\hline 25. & I. modesta & 5 & 1.80 & 0.09 & 24.30 & 0.25 & 0.02 & 0.02 & 0.29 & 0.10 \\
\hline 26. & Microlepia manjuscula & 18 & 1.44 & 0.26 & 54.60 & 0.89 & 0.05 & 0.05 & 0.99 & 0.33 \\
\hline 27. & Myriactis wightii & 21 & 2.19 & 0.46 & 133.40 & 1.04 & 0.09 & 0.12 & 1.25 & 0.42 \\
\hline 28. & Odontosoria chinensis & 19 & 1.84 & 0.35 & 115.50 & 0.94 & 0.07 & 0.11 & 1.12 & 0.37 \\
\hline 29. & Oxalis corniculata & 63 & 5.06 & 3.19 & 988.90 & 3.13 & 0.64 & 0.90 & 4.67 & 1.56 \\
\hline 30. & O. pubescens & 71 & 5.70 & 4.05 & 1215.00 & 3.53 & 0.81 & 1.11 & 5.45 & 1.82 \\
\hline 31. & Pilea trinervia & 21 & 1.43 & 0.3 & 84.00 & 1.04 & 0.06 & 0.08 & 1.18 & 0.39 \\
\hline 32. & P. wightii & 23 & 1.78 & 0.41 & 127.10 & 1.14 & 0.08 & 0.12 & 1.34 & 0.45 \\
\hline 33. & $\begin{array}{l}\text { Pogostemon } \\
\text { travancoricus }\end{array}$ & 36 & 1.81 & 0.65 & 195.00 & 1.79 & 0.13 & 0.18 & 2.10 & 0.70 \\
\hline 34. & Polygonum chinense & 23 & 1.22 & 0.28 & 112.00 & 1.14 & 0.06 & 0.10 & 1.30 & 0.43 \\
\hline 35. & Psoralea pinnata & 42 & 1.07 & 0.45 & 139.50 & 2.09 & 0.09 & 0.13 & 2.31 & 0.77 \\
\hline 36. & Pteris cretica & 60 & 1.05 & 0.63 & 157.50 & 2.98 & 0.13 & 0.14 & 3.25 & 1.08 \\
\hline 37. & P. quadriauriata & 85 & 1.09 & 0.93 & 251.10 & 4.22 & 0.19 & 0.23 & 4.64 & 1.55 \\
\hline 38. & Rubus racemosus & 30 & 1.37 & 0.41 & 196.80 & 1.49 & 0.08 & 0.18 & 1.75 & 0.58 \\
\hline 39. & R. ellipticus & 41 & 1.29 & 0.53 & 238.50 & 2.04 & 0.11 & 0.22 & 2.37 & 0.79 \\
\hline 40. & Solanum nigrum & 19 & 1.63 & 0.31 & 96.10 & 0.94 & 0.06 & 0.09 & 1.09 & 0.36 \\
\hline 41. & $\begin{array}{l}\text { Strobilanthes } \\
\text { kunthiana }\end{array}$ & 8 & 1.63 & 0.13 & 54.60 & 0.40 & 0.03 & 0.05 & 0.48 & 0.16 \\
\hline 42. & Thalictrum javanicum & 11 & 3.82 & 0.42 & 172.20 & 0.55 & 0.08 & 0.16 & 0.79 & 0.26 \\
\hline 43. & Ulex europaeus & 16 & 2.38 & 0.38 & 133.00 & 0.79 & 0.08 & 0.12 & 0.99 & 0.33 \\
\hline 44. & Viola serpens & 31 & 1.48 & 0.46 & 96.60 & 1.54 & 0.09 & 0.09 & 1.72 & 0.57 \\
\hline 45. & V. patrinii & 35 & 1.57 & 0.55 & 99.00 & 1.74 & 0.11 & 0.09 & 1.94 & 0.65 \\
\hline
\end{tabular}

F-Frequency; A-Abundance; D-Density; B-Basal cover; R.F- Relative frequency, R.De- Relative density, R.Do- Relative dominance, IVIImportance value index , RVI- Relative value of importance.

\section{ACKNOWLEDGEMENT}

The authors graciously acknowledge Dr.M. Aruchami Research Foundation for providing financial support to carry out this work.

\section{REFERENCES}

Chandrasekaran, S. and P.S. Swamy, (1995). Changes in the herbicious vegetation following disturbances due to biotic interference in natural and man-made ecosystems in Western Ghats. Trop. Ecol. 36: 213-220.

Cottom, G. and J.T. Curtis, (1956). The use of distance measure in phytosociological sampling. Ecol. 37(3): 451-460.

Curtis, J.T. and R.P.M.C. Intosh, (1950). The interrelations of certain analytic and synthetic phytosocioligal characters. Ecol. 31(3): 434455.

Daubenmire, R. F, (1970). Plants and Environment. 2nd Edition. Wiley Eastern Private Limited, New Delhi. p. 422 .

Daubenmire, R. F. (1940). Plant succession due to overgrazing in the Agropyron bunch grass prairie in the southeastern Washington. Ecol.. 21(1): 55-64.

Dyksterhuis, E. J, (1949). Conditions and management of rangeland based on quantitative ecology. J. Range Management. 2: 104-115.

Katsuno, T. (1977). Phytosociological studies on the road side vegetation. Part 1. Bull. Coll. Agric. Vet. Med. Nihon Uty. 34: 311-343. 
Khoshoo, T N. and C. Mahal, (1967). Versatile reproduction in Lantana camara. Curr. Sci. 36: 201-203.

Manoj, K., M.R. Nandakumar, M.R. Remya, K. Shinila and P. Divya Lakshmi, (2012). Phytosociological analysis of riparian tree species of Alakyam stream; Pariyaram, Kerala, India. Inter $J$ Environment. Sci. 2(4): 1895-1903.

Manorama, S. (1996). Studies on the natural regeneration of lime mined sitesat Madukkarai, Coimbatore District, Tamil Nadu, India. Ph.D., Thesis, Bharathiar, Coimbatore, India.

Meher-Homji, V.M, (1967). Phytogeography of the South Indian hill stations. Bulletin of the Torrey Botanical Club. 94 (4): 230-242.

Michael, P.O. and N. Boodram, (2006). The dry forest vegetation communities of little Tobago island, West Indies: floristic affinities. Trop. Ecol. 47(2): 211-228.

Paulsamy, S. (2005). Annual progress report of the project, "Evaluation of conservation strategies for the sustainable utilization of herbaceous bioresources in the sholas of Nilgiris, the Western Ghats, sponsored by Ministry of Environment and Forest, Govt. of India, New Delhi.
Paulsamy, S. (2006). Evaluation of conservation strategies for the sustainable utilization of herbaceous bioresources in the sholas of Nilgiris, the Western Ghats. Annual Progress Report, Ministry of Environment and Forests Scheme, Govt. of India, New Delhi.

Paulsamy, S. (2007). Annual Progress Report, Ministry of Environment and Forests, Government of India, New Delhi sponsored project, "Evaluation of conservation strategies for the sustainable utilization of herbaceous bioresources in the sholas of Nilgiris, the Western Ghats" (File No. 08/ 16/03.CS /BR).

Von lengerke, H.J. (1977). The Nilgiris: Weather and climate of a mountain area in South India. Franz steiner verlag GMBH, Wiesbaden, Germany.

Weaver, J.E. and F.W. Albertson, (1956). Grasslands of the great plains. Johnson Publ.Co., Lcoln, Nbraska. p. 395.

Weaver, J.E. and W.W. Hansen, (1941). Native midwestern pastures; their origin; composition and degradation. Agronomy and HorticultureFaculty publications 22: 93. 